\title{
Tenure \& Turnover among State Health Officials from the SHO-CASE Survey: Correlates \& Consequences of Changing Leadership
}

\author{
Nir Menachemi, PhD, MPH \\ IU Fairbanks School of Public Health \\ 1050 Wishard Boulevard, Indianapolis, IN, 46202 \\ nirmena@iu.edu \\ Elizabeth C. Danielson, MA \\ IU Fairbanks School of Public Health \\ 1050 Wishard Boulevard, Indianapolis, IN, 46202 \\ ecdaniel@umail.iu.edu \\ Hugh Tilson, MD, DrPH \\ IU Fairbanks School of Public Health \\ 1050 Wishard Boulevard, Indianapolis, IN, 46202 \\ htilson@email.unc.edu \\ Valerie A. Yeager, DrPH \\ IU Fairbanks School of Public Health \\ 1050 Wishard Boulevard, Indianapolis, IN, 46202 \\ vyeager@iu.edu \\ Katie Sellers, PhD \\ de Beaumont Foundation \\ 7501 Wisconsin Avenue, Suite 1310E, Bethesda, MD, 20814 \\ sellers@debeaumont.org
}

Paul K. Halverson, DrPH, FACHE for the SHO-CASE Steering Committee

IU Fairbanks School of Public Health

1050 Wishard Boulevard, Indianapolis, IN, 46202

pkhalver@iu.edu

\begin{abstract}
Acknowledgements
Additional authors for the SHO-CASE Steering Committee include Edward L. Baker, Brian C. Castrucci, Steven Boedigheimer, Corey M. Jacinto, and Glen P. Mays. The SHO-CASE study is a collaborative effort between the Indiana University Richard M. Fairbanks School of Public Health, de Beaumont Foundation, and the Association of State and Territorial Health Officials (ASTHO). We would like to thank ASTHO for supporting and facilitating the survey and historical data collection and the de Beaumont Foundation for their financial support of the SHO-CASE Study.
\end{abstract}

Conflicts of Interest and Source of Funding: This work was funded by the de Beaumont Foundation.

This is the author's manuscript of the article published in final edited form as:

Menachemi, N., Danielson, E. C., Tilson, H. A., Yeager, V. A., Sellers, K., Halverson, P. K., \& SHO-CASE Steering Committee. (2020). Tenure and Turnover Among State Health Officials From the SHO-CASE Survey: Correlates and Consequences of Changing Leadership. Journal of Public Health Management and Practice: JPHMP, 26(1), 23-31. https://doi.org/10.1097/PHH.0000000000000991 


\title{
Tenure \& Turnover among State Health Officials from the SHO-CASE Survey: Correlates \& Consequences of Changing Leadership
}

\begin{abstract}
Objective: To examine characteristics associated with tenure length of State Health Officials (SHOs); and examine reasons and consequences for SHO turnover.

Design: Surveys of current and former SHOs linked with secondary data from the United Health Foundation.
\end{abstract}

Setting: Original survey responses from SHOs in the United States.

Participants: Respondent included SHOs who served between 1973-2017.

Main Outcome Measures: Tenure length and consequences of SHO turnover.

Results: Average completed tenure among SHOs was 5.3 years (median $=4$ ) and was shorter in recent time periods compared with decades prior. Older age at appointment $(b=-0.109, p=0.005)$ and those holding a management degree $(b=-1.835, p=0.017)$ and/or a law degree $(b=-3.553, p<0.001)$ were each associated with shorter SHO tenures. SHOs from states in the top quartile for health rankings had significantly longer average tenures $(b=1.717, p=0.036)$. Many former SHOs believed their tenure was too short and reported that their departure had either a significant or very large effect on their agency's ability to fulfill its mission.

Conclusions: SHO tenures have become shorter over time and continue to be shorter than industry CEOs and best practice recommendations from organizational researchers. States have an opportunity to consider, and address, how factors within their control influence the stability of the SHO position.

Key words: State Health Official; Tenure; Turnover; Public Health; Leadership 


\section{Introduction}

State Health Officials (SHOs) are responsible for leading their state health department; and are thus responsible for leading most public health issues in their jurisdiction. Traditionally, state health departments have focused on preventing the spread of infectious diseases, reducing accidents and injuries, assuring safe water, food, and air quality, and operating state public health laboratories. ${ }^{1}$ Over the decades, as public health has taken on additional responsibilities pertaining to disaster preparedness, chronic disease prevention, environmental health risks, and the opioid epidemic, the job of the SHO has become more complex with an increasing scope. This has resulted in calls for SHOs to also serve as chief health strategist in their states. ${ }^{2}$ In industry, complexity and scope add to job stress ${ }^{3}$ which can result in disruptive turnover. ${ }^{4,5}$

Organizational researchers have studied the impact of leadership turnover in a variety of industries. ${ }^{6,7}$ Much attention has been focused on the impact and antecedents of chief executive officer (CEO) turnover in hospitals, ${ }^{8,9}$ sports teams, ${ }^{10,11}$ and large public corporations. ${ }^{12}$ Less is known about turnover among SHOs. Importantly, SHOs are most commonly appointed by entities (e.g., governors or boards of health $)^{13}$ who may select individuals based on personal relationships, political recommendations, ideology, or some other trait that does not necessarily prepare someone to lead a public health agency. In the only empirical study regarding SHO term lengths, Halverson et al (2017) reported that SHOs typically serve for an average of 4.1 years; and the length of tenure has become shorter over time from the 1980 's to the present. ${ }^{14}$ Given data limitations, the previous study was unable to determine if key individual characteristics, such as age, previous experience, or educational backgrounds are associated with SHO tenure or premature turnover.

In the current study, we seek to build upon previous work by more comprehensively examining tenure and turnover among SHOs. To do so, we make use of newly collected data from the State Health Official - Career Achievement Sustainability Evaluation (SHO-CASE) Study which targeted all living 
current and former SHOs in the US. ${ }^{15}$ Specifically, we analyze responses from SHOs to estimate their average tenure, list the most common reasons for voluntary and involuntary turnover, and determine individual and state characteristics associated with tenure length. Lastly, we present data on the perceived impact that SHO departure had on their organizations. We believe our results will be of value to stakeholders interested in improving the continuity of leadership in state health departments, governors, and others responsible for appointing SHOs.

\section{Methods}

We analyze primary survey data collected as part of the SHO-CASE Study. For the current analysis, we were interested in factors related to SHO tenure length, turnover, and activities that occur after the SHOs leave the job. Our data come from two related surveys targeting all living former and current SHOs. The first survey (primary survey) gathered general information including demographics, term length, and reasons for departure. A follow up survey captured more in-depth information about SHO turnover and departure experience. The study received human subjects approval from the Institutional Review Board at the university of the primary author and a complete description of the data collection methodology has been previously published. ${ }^{15}$

Our primary dependent variable was tenure length, captured from each respondent regarding as many as 3 potentially non-contiguous SHO appointments. In addition, the survey included questions about the reasons that former SHOs left their position. Respondents were able to select up to 9 reasons including an 'other' free response category. The categories included voluntary and involuntary reasons for turnover. Irrespective of the reason for turnover, former SHO respondents were then asked to select the sector (e.g., public health, academia, healthcare delivery, etc.) where they were employed immediately after serving as SHO. 
Independent variables included various demographic and state characteristics of SHOs and the states where they served. Demographic characteristics included gender, age at SHO appointment, race, ethnicity, and educational attainment. Educational attainment was measured using binary non-mutually exclusive categories for degrees in: public health, medicine, management, and law. State characteristics included US Census region, governance structure (centralized, shared, mixed, or decentralized), SHO appointing authority (governor, secretary of health, or board of health) and state health ranking data from United Health Foundation ${ }^{16}$ expressed as binary variables measuring bottom or top quartile for ranking in that year. In addition, we used information regarding the decade of the appointment categorized as: 2010s, 2000s, 1990s, and a combined category of 1980s and 1970s (due to smaller sample sizes). Lastly, the survey asked former SHOs to identify perceived personal attributes or capabilities that they believed were most critical to their own job performance. A list of 10 attributes or capabilities was provided and SHOs were asked to select the three most important to their performance. Given our focus on SHO tenure, we examined how selecting different attributes or capabilities was related to average tenure as SHOs.

Our statistical analyses include frequency counts and examinations of central tendency. We used independent sample t-tests or analyses of variance (ANOVA), as needed, to examine the relationship between average tenure and each of the independent variables described above. Where appropriate, we present data for current and former SHOs separately. In addition, we used Chi-square tests to examine the relationship between voluntary vs. involuntary turnover and the sector where employment was gained following appointment as SHO. Lastly, we used an ordinary least square regression model to examine how each of our independent variables was associated with tenure length. In this model, we also included indicator variables for being a current $\mathrm{SHO}$, the number of tenures served, and clustered observations by person ID to account for repeated observations (e.g., when a 
given individual served more than one term). Analyses were performed in SPSS v.24 and statistical significance was considered at the $p<0.05$ level.

\section{Results}

Overall, $47.3 \%$ ( $n=96 / 203$ ) of former and $86.4 \%(n=51 / 59)$ of current SHOs responded to the primary survey, representing a combined participation rate of $56.1 \%(n=147 / 262)$. Demographic characteristics of those included in the current study appear in Table 1. Briefly, former SHOs made up two-thirds $(65.3 \%, n=96 / 147)$ of respondents; and a majority of all respondents were male $(61.2 \%$, $n=90 / 147)$, white $(83.5 \%, n=116 / 139)$, and served in only one state $(91.2 \%, n=134 / 147)$. Mean age at SHO appointment was 49.9 years with a range from 29 to 74 . Average completed tenure among former SHOs was 5.3 years (median= 4.0 years); and ongoing tenure among current SHOs was 2.8 years (median 2.5 years).

Correlates of tenure length

In Table 2, we present average tenure by various demographic characteristics for both former and current SHOs. Among former SHOs, having a management (3.9 vs. 5.7 years; $p=0.007$ ) or law degree ( 2.8 vs. 5.5 years; $p=0.044)$ was associated with significantly shorter tenures. Moreover, average tenure by decade was shortest in the 2010's (mean 2.9 years) and was significantly shorter than prior decades $(p=0.003)$. Among current SHOs, respondents with a public health degree had longer tenures than their counterparts ( 3.4 vs. 2.1 years; $p=0.022$ ). No other demographic characteristic was associated with tenure in bivariate analyses. 
In Table 3, we present the adjusted factors associated with tenure that were estimated in a regression model. We found that each additional year of age at SHO appointment $(\beta=-0.109, p=0.005)$ and having either a management $(\beta=-1.835, p=0.017)$ or law degree $(\beta=-3.553, p<0.001)$ were independently associated with shorter tenures. Moreover, states in the best quartile for health rankings had significantly higher average tenures $(\beta=1.717, p=0.036)$ than other states. SHO tenures in all prior decades were significantly longer than those from the 2010's (all p<0.05). Lastly, SHOs appointed by secretaries of health had shorter tenures $(\beta=-1.264, p=0.05)$ than those appointed by governors (the reference group).

Perceived critical leadership attributes and tenure length among former SHOs

Former SHOs were provided a list of 10 attributes and capabilities and asked to select the three they believed were the most important to their own job performance as SHO. The frequency at which respondents selected each attribute, and the associated average tenure for those selecting each item, is displayed in Table 4. Respondents who selected the personal attribute of "integrity" had significantly shorter average tenures than their counterparts ( 3.9 vs. 5.3 years; $p=0.038$ ). On the other hand, respondents who selected either "ability to establish trust relationships with outside partners" (5.9 vs. 3.9; $p=0.030$ ) or "ability to establish trust relationships with the governor's office" (6.1 vs. 4.1; $p=0.050)$ had significantly longer tenures than those who did not select these items. No other attribute was associated with tenure length.

Voluntary and involuntary turnover among former SHOS 
Former SHOs were asked questions to determine whether their term ended on either a voluntary or involuntary basis. Overall, $54.2 \%$ of turnover was involuntary (including turnover in anticipation of a change in gubernatorial political party). Reasons for voluntary and involuntary turnover among former SHOs is presented in Table 5. The most common reasons for involuntary turnover included accepting another position in anticipation of a change in state administration (43.2\%), a new administration appointed another SHO (36.4\%) and having been terminated involuntarily (22.7\%). The most common reasons for voluntary turnover were being offered another position (47.2\%), resigning without securing another job (22.2\%), and having accomplished what was set out (19.4\%).

Former SHOs were also asked to identify the sectors (not mutually exclusive) in which they obtained a job immediately after serving as a SHO. As shown in the Appendix, the most common sectors, overall, of post-SHO employment were public health (46\%), academia $(30.2 \%)$, health care (20.6\%), and nonprofits including philanthropy (20.6\%). When comparing sectors of employment by those who experienced voluntary versus involuntary turnover, we observe that SHOs with involuntary turnover were more likely to obtain employment in the public health sector $(57.1 \%$ vs. $32.1 \%, p=0.048)$ after serving as SHO.

Turnover impact on the organization

Former SHOs were asked what impact their departure had on their agency's ability to fulfill its mission [Likert categories: no effect, little effect, some effect, significant effect, very large effect]. Responses were combined such that those who indicated 'significant' or 'very large' effect were categorized together. Overall, $25.9 \%$ indicated that their departure had a significant or very large effect on their agency's ability to fulfill its mission. Those who indicated that their departure had at a significant or very large effect had marginally shorter average tenure lengths (3.9 vs. 5.4 years; $p=0.087$ ). 
Former SHOs were asked for their perceptions regarding the length of time they served and whether they believed it was: too short, about right, or too long to have an optimal impact on agency performance. No respondents selected too long; $54.8 \%$ believed their tenure was about right, and $45.2 \%$ believed their tenure was too short. Those believing their tenures were too short had significantly shorter tenure lengths ( 3.2 vs. 6.7 years; $p<0.001)$.

\section{Discussion}

In the most comprehensive examination of SHO tenure and turnover to date, we found that average tenure was associated with several individual demographic characteristics, some state characteristics, and some perceived critical leadership attributes among SHOs. In addition, we documented experiences in post-SHO employment as well as voluntary and involuntary turnover. Lastly, we obtained information from SHOs regarding how they perceived their turnover affected their agencies.

Overall, we found that the average tenure of former SHOs was 5.3 years with a median of 4.0 years. When including current SHOs in the average (data not shown above), we found a mean tenure of 4.2 years (median $=3.0$ ) which is very similar to the estimates previously reported by Halverson et al (2017). Research from industry has explored the benefits and drawbacks of tenure length among CEOs. The benefits of longer tenures include time for on-the-job learning by CEOs, improved experience and confidence, and better relationships with internal and external stakeholders. ${ }^{17}$ However, the drawbacks of long CEO tenures may include an increased potential for a mismatch between the CEO's capabilities and the firm's needs; and increased managerial entrenchment. According to researchers, the "sweet spot" for CEO tenures among large firms was about 12 years despite the mean being almost 8 years. ${ }^{18}$ Given the shorter typical tenures of SHOs, more research is needed to determine the organizational 
drawbacks associated with less time for these leaders to impact their organizations. In other words, it is worth examining the negative consequences, if any, to public health agencies and their employees as a result of current SHO tenures.

Importantly, we found that SHOs with either a management or a law educational background served, on average, shorter tenures than those with medical or public health degrees. These shorter tenures were not associated with involuntary turnover (data not shown). It is possible that SHOs with management degrees are sought when the appointing authority perceives that the health department requires administrative or structural overhaul; and once that is achieved, these SHOs are more likely to leave their position. Similarly, those with a law degree may be more likely to be appointed when decision-makers believe that policy changes or legal issues need to be addressed to improve the standing of the health department. Policy and legal changes frequently require legislative action which can become politically challenging. Thus, it may be possible that SHOs with a law degree are selected for tasks that require greater than normal engagement in the political process, which may ultimately result in shorter tenure. We note that SHOs who perceived their ability to partner with outside entities or the governor's office as critical to their success, had longer average tenures. This finding aligns with related work from the SHO-CASE Study that emphasized the value of the SHO building relationships with external partners. ${ }^{19}$ It is possible that skills in partnership formation contribute positively to SHO tenure; whereas situations that call for major changes (e.g., administrative restructuring or legal/policy changes) lead to shorter tenures. Lastly, SHOs appointed by secretaries of health (as opposed to governors) had shorter average tenures.

We also found that age was negatively associated with tenure such that being younger at the time of SHO appointment was associated with a longer tenure. One potential reason for this finding is that younger SHOs, given their longer career time horizons, and overall familial responsibilities, may be less willing to take risks in their SHO roles that put their positions in jeopardy. Higher CEO age is known 
to be correlated with better firm stock performance, largely because studies have shown that older CEOs tend to make less risky decisions. ${ }^{20}$ Unfortunately, our study was unable to examine risk-taking behavior of SHOs, but more research should further examine how age, tenure, and organizational performance are related in the context of state public health agencies.

SHOs appointed in states that at the time of appointment, were in the top quartile on health rankings served longer average tenures. At least three possible explanations for this finding exist. First, states with superior health status may have greater public health infrastructure, funding, and political support ${ }^{21}$ which may result in greater stability to the health department and thus longer SHO tenures. Second, states with superior health rankings may have processes in place that attract more capable leaders-especially on difficult to measure attributes, and these more personally capable SHOs stay on the job longer than their counterparts in other states. Lastly, it is possible that historically longer SHO tenure in a given state may contribute to improvements in population health which ultimately results in superior health rankings. Further inquiry into how state health environments influence SHO selection and tenure is warranted.

With respect to turnover, we found that involuntary turnover occurred in more than half of all appointments. The most cited reasons for involuntary turnover was accepting another job in anticipation of a new administration or because a new administration appointed a new SHO. This may not be surprising given that governors or other political appointees are the most common appointers of SHOs; and governors are typically up for re-election every 4 years. Of note, almost half of our respondents indicated that their tenure was too short; and about one quarter believed their turnover had a significant effect on their agency's ability to fulfill its mission. Two interesting opportunities for future research are to examine whether governor's political affiliation is associated with average tenure lengths of SHOs and explore the relationship between involuntary turnover and subsequent work within governmental public health. 
SHOs are frequently recruited into other jobs and we found that the most common sectors for post-SHO employment were public health and academia. While the reason for turnover was not systematically associated with the sector of post-SHO employment, the fact that SHOs who experience involuntary turnover were significantly more likely to obtain a job in public health was notable. Importantly, post-SHO employment in the public health sector may occurs at the federal, state, or local level-given that experience as a SHO provides unique insights into opportunities to be effective at each level of public health practice.

Despite the new findings that our study provides, there are several limitations worth mentioning. First, our overall survey achieved a 56\% response rate; and former SHOs from which our turnover analyses stem responded at a rate of $47 \%$. While these response rates are generally considered adequate, especially when the target population includes physicians, ${ }^{22}$ we recognize that with less than full participation, our findings are potentially affected by nonresponse bias. Second, irrespective of our response rate, our study is limited by self-reported data and small sample sizes that result in limited statistical power to explore correlates of tenure and turnover. Ultimately, the population of living current and former SHOs represents a relatively small cohort of research subjects. Third, some of our findings are limited by secondary data availability. For example, the state health rankings from United Health Foundation were only available beginning in 1990. As such, SHO respondents who served prior to this year did not have rankings data and, consistent with standard practice, ${ }^{23}$ were subsequently assigned the median value to include them in the regression analysis. Further, we recognize that other ranking systems exist (e.g., Commonwealth Fund) that may have yielded different findings. Another limitation stems from the fact that SHO tenure was not measured to include months in the estimates. Thus, if a respondent served across 2 different years (e.g., August to March), they may have served less time than the estimate we derived (e.g., 1 year in this case). Lastly, 
our data are cross-sectional in nature and do not allow us to guard against selection bias. Thus, the relationships we identify are to be interpreted as associations and not cause-and-effect.

\section{Implications for Policy \& Practice}

Overall, we have found that SHO tenure is typically 4 to 5 years with significantly shorter tenures in recent times. In addition, these tenures, even at their peak, are shorter than leaders of other organizations at the CEO level-and shorter than what is ideally recommended by researchers who have focused on industry. It is unknown whether these tenures are shorter than other political appointees in government. However, given that several individual and state-related attributes were associated with tenure length, states should be encouraged to examine the tenure trends of their own SHOs and determine if there are barriers that can be addressed to improve the stability and effectiveness of their state public health leader. For example, Rhode Island statues specify 5-year fixed terms for SHOs, noting that they are renewable for additional terms. ${ }^{24}$ The statute does not guarantee that a SHO will be allowed to serve the full 5 years, but it does provide a term that may stabilize the individual's role to some extent. It may also improve the ability of a SHO to implement change consistent with the needs of the agency and the population served. 
Table 1: Characteristics of Individual SHO Respondents ( $n=147)$

\begin{tabular}{|c|c|c|c|}
\hline \multicolumn{3}{|l|}{ Variable } & Frequency (\%) \\
\hline \multicolumn{3}{|c|}{$\begin{array}{l}\text { Former } \mathrm{SHO} \\
\text { Current SHO }\end{array}$} & $\begin{array}{l}96(65.3 \%) \\
51(34.7 \%)\end{array}$ \\
\hline Gender: & \multicolumn{2}{|l|}{$\begin{array}{l}\text { Male } \\
\text { Female }\end{array}$} & $\begin{array}{l}90(61.2 \%) \\
57(38.8 \%)\end{array}$ \\
\hline \multicolumn{3}{|c|}{$\begin{array}{l}\text { Mean Age at Appointment (SD) } \\
\text { Range }\end{array}$} & $\begin{array}{l}49.9 \text { years }(8.9) \\
29-74 \text { years }\end{array}$ \\
\hline Race: & $\begin{array}{l}\text { White } \\
\text { Black or Afr } \\
\text { Asian } \\
\text { Other inclu }\end{array}$ & $\begin{array}{l}\text { American } \\
2 \text { or more races }\end{array}$ & $\begin{array}{l}116(83.5 \%) \\
10(7.2 \%) \\
9(6.5 \%) \\
4(2.9 \%)\end{array}$ \\
\hline Ethnicity: & \multicolumn{2}{|c|}{ Hispanic } & $\begin{array}{l}3(3.2 \%) \\
90(96.8 \%)\end{array}$ \\
\hline Number c & $\begin{array}{l}\text { terms per } r \\
\text { One } \\
\text { Two } \\
\text { Three }\end{array}$ & ondent & $\begin{array}{l}134(91.2 \%) \\
11(7.5 \%) \\
2(1.4 \%)\end{array}$ \\
\hline \multicolumn{2}{|c|}{ US Region of SHO service ${ }^{1}$ : } & $\begin{array}{l}\text { Northeast } \\
\text { South } \\
\text { Midwest } \\
\text { West } \\
\text { US Territory }\end{array}$ & $\begin{array}{l}31(19.1 \%) \\
46(28.4 \%) \\
41(25.3 \%) \\
41(25.3 \%) \\
3(1.9 \%)\end{array}$ \\
\hline \multicolumn{3}{|c|}{ 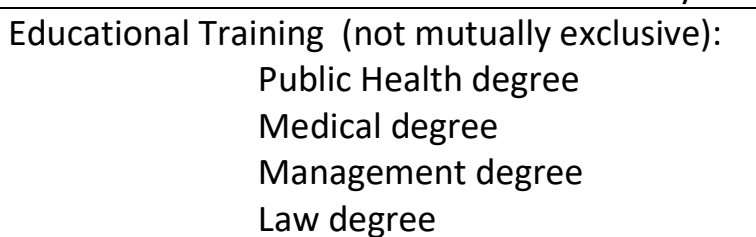 } & $\begin{array}{l}71(48.3 \%) \\
95(64.6 \%) \\
32(21.8 \%) \\
14(9.5 \%)\end{array}$ \\
\hline \multicolumn{3}{|c|}{$\begin{array}{l}\text { Completed tenure among former } \mathrm{SHOs}^{1}(\mathrm{n}=96) \\
\text { Mean (S.D.) } \\
\text { Median }\end{array}$} & $\begin{array}{l}5.3(4.1) \\
4.0\end{array}$ \\
\hline \multicolumn{3}{|c|}{$\begin{array}{l}\text { Ongoing tenure among current SHOs }(n=51) \\
\text { Mean (S.D.) } \\
\text { Median }\end{array}$} & $\begin{array}{l}2.8(2.1) \\
2.5\end{array}$ \\
\hline
\end{tabular}

${ }^{1} \mathrm{SHOs}$ with multiple terms of service can be represented more than once 
Table 2: Average tenure by individual characteristics among Former and Current SHOs

\begin{tabular}{|c|c|c|c|c|c|c|}
\hline & & & $\begin{array}{l}\text { Average Tenure in Years } \\
\text { among FORMER SHOs }\end{array}$ & P-value $^{3}$ & $\begin{array}{l}\text { Average Tenure in Years } \\
\text { among CURRENT SHOs }\end{array}$ & P-value \\
\hline Gender: & \multicolumn{2}{|c|}{$\begin{array}{l}\text { Male } \\
\text { Female }\end{array}$} & $\begin{array}{l}5.0 \\
5.8\end{array}$ & 0.393 & $\begin{array}{l}2.7 \\
2.9\end{array}$ & 0.742 \\
\hline Race: & \multicolumn{2}{|c|}{$\begin{array}{l}\text { White } \\
\text { Other } \\
\text { Unknown }\end{array}$} & $\begin{array}{l}5.4 \\
4.7 \\
5.0 \\
\end{array}$ & 0.849 & $\begin{array}{c}3.00 \\
2.1\end{array}$ & 0.078 \\
\hline \multicolumn{2}{|c|}{ Public Health Degree: } & $\begin{array}{l}\text { Yes } \\
\text { No }\end{array}$ & $\begin{array}{l}5.9 \\
4.7 \\
\end{array}$ & 0.176 & $\begin{array}{l}3.4 \\
2.1 \\
\end{array}$ & 0.022 \\
\hline \multicolumn{2}{|c|}{ Medical Degree: Yes } & No & $\begin{array}{l}5.0 \\
5.7 \\
\end{array}$ & 0.460 & $\begin{array}{l}2.8 \\
2.7\end{array}$ & 0.815 \\
\hline \multicolumn{2}{|c|}{ Management Degree: } & $\begin{array}{l}\text { Yes } \\
\text { No }\end{array}$ & $\begin{array}{l}3.9 \\
5.7 \\
\end{array}$ & 0.007 & $\begin{array}{l}2.7 \\
2.8 \\
\end{array}$ & 0.928 \\
\hline Law Degree: & & $\begin{array}{l}\text { Yes } \\
\text { No }\end{array}$ & $\begin{array}{l}2.8 \\
5.5\end{array}$ & 0.044 & $\begin{array}{l}1.7 \\
2.9 \\
\end{array}$ & 0.280 \\
\hline \multicolumn{3}{|c|}{$\begin{array}{l}\text { SHO held a position in governmental } \\
\text { public health prior to appointment: } \\
\qquad \text { Yes } \\
\text { No }\end{array}$} & $\begin{array}{l}5.4 \\
5.3\end{array}$ & 0.972 & $\begin{array}{l}2.9 \\
2.4\end{array}$ & 0.458 \\
\hline Census Region: & $\begin{array}{l}\text { North } \\
\text { Midw } \\
\text { Soutr } \\
\text { West } \\
\text { US Te }\end{array}$ & ist & $\begin{array}{l}4.7 \\
5.5 \\
4.4 \\
6.6\end{array}$ & 0.298 & $\begin{array}{l}1.6 \\
2.3 \\
3.5 \\
2.7\end{array}$ & 0.195 \\
\hline Decade: 1970 s \& & $\begin{array}{l}1980 \\
1990 \\
2000 \\
2010\end{array}$ & & $\begin{array}{l}5.9 \\
7.2 \\
4.8 \\
2.9\end{array}$ & 0.003 & N/A & \\
\hline Healthy State: ${ }^{1}$ & & $\begin{array}{l}\text { Yes } \\
\text { No }\end{array}$ & $\begin{array}{l}6.5 \\
4.7 \\
\end{array}$ & 0.062 & $\begin{array}{l}2.5 \\
2.8 \\
\end{array}$ & 0.788 \\
\hline Unhealthy State ${ }^{2}$ : & & $\begin{array}{l}\text { Yes } \\
\text { No }\end{array}$ & $\begin{array}{l}4.7 \\
5.7 \\
\end{array}$ & 0.556 & $\begin{array}{l}2.9 \\
2.6 \\
\end{array}$ & 0.641 \\
\hline $\begin{array}{r}\text { Governance Struc } \\
\text { Centraliz } \\
\text { Shared } \\
\text { Mix } \\
\text { Decentra }\end{array}$ & $\begin{array}{l}\text { cture: } \\
\text { zed } \\
\text { alized }\end{array}$ & & $\begin{array}{l}5.3 \\
4.2 \\
5.0 \\
5.4 \\
\end{array}$ & 0.922 & $\begin{array}{l}2.7 \\
3.5 \\
3.6 \\
2.4\end{array}$ & 0.627 \\
\hline $\begin{array}{r}\text { Appointment Autt } \\
\text { Governor } \\
\text { Secretary } \\
\text { Board of }\end{array}$ & $\begin{array}{l}\text { hority } \\
\text { r of } \mathrm{H} \\
\text { f Healt }\end{array}$ & & $\begin{array}{l}5.3 \\
4.3 \\
3.5\end{array}$ & 0.481 & $\begin{array}{l}2.4 \\
2.7 \\
5.5\end{array}$ & 0.060 \\
\hline
\end{tabular}

Notes: ${ }^{1}$ Healthy states are those ranked in the top 12 (top quartile) on United Health Foundation rankings at the time of $\mathrm{SHO}$ appointment.

${ }^{2}$ Unhealthy states are those ranked in the bottom 12 (bottom quartile) on United Health Foundation rankings at the time of SHO appointment.

${ }^{3}$ Statistical significance was considered at the $p<0.05$ level. 
Table 3: Factors associated with tenure length among SHOs ( $n=162$ tenures among $n=147$ individuals)

\begin{tabular}{|c|c|}
\hline Independent Variables & $\begin{array}{l}\text { Dependent Variable: } \\
\text { Length of Tenure }\end{array}$ \\
\hline Current SHO & $-0.705(.819)$ \\
\hline Male gender & $-0.134(.606)$ \\
\hline White race & $0.396(.839)$ \\
\hline Age at appointment in years & $-0.109(.040)^{* *}$ \\
\hline Prior governmental public health experience & $0.805(.707)$ \\
\hline $\begin{array}{l}\text { Educational Training (not mutually exclusive) } \\
\text { SHO has medical degree } \\
\text { SHO has public health degree } \\
\text { SHO has management degree } \\
\text { SHO has law degree }\end{array}$ & $\begin{array}{c}\text { Reference } \\
-0.232(.628) \\
-1.835(.710)^{*} \\
-3.553(.934)^{* * *}\end{array}$ \\
\hline $\begin{array}{l}\text { Census region } \\
\text { South } \\
\text { Northeast } \\
\text { Midwest } \\
\text { West }\end{array}$ & $\begin{array}{c}\text { Reference } \\
-1.183(1.193) \\
-0.661(1.107) \\
0.403(.985)\end{array}$ \\
\hline $\begin{array}{l}\text { Decade of appointment: } \\
\text { 2010s } \\
2000 \text { s } \\
1990 \text { s } \\
1970 \text { s or } 1980 \text { s }\end{array}$ & $\begin{array}{c}\text { Reference } \\
1.835(.890)^{*} \\
4.143(1.100)^{* * *} \\
2.02(1.245)^{*}\end{array}$ \\
\hline $\begin{array}{l}\text { State Health Ranking: } \\
\text { Best quartile } \\
\text { Worst quartile }\end{array}$ & $\begin{array}{c}1.717(.804)^{*} \\
.392(.850)\end{array}$ \\
\hline $\begin{array}{l}\text { Governance Structure } \\
\text { Centralized } \\
\text { Shared } \\
\text { Mixed } \\
\text { Decentralized }\end{array}$ & $\begin{array}{c}\text { Reference } \\
-0.570(1.243) \\
-0.327(1.167) \\
-1.016(.826)\end{array}$ \\
\hline $\begin{array}{l}\text { Appointing Authority } \\
\text { Governor } \\
\text { Secretary of Health } \\
\text { Board of Health }\end{array}$ & $\begin{array}{c}\text { Reference } \\
-1.264(.643)^{*} \\
-0.455(1.601)\end{array}$ \\
\hline Model F Statistic & $4.245^{* * *}$ \\
\hline Adjusted $\mathrm{R}^{2}$ & 0.380 \\
\hline
\end{tabular}

Notes: Values in cell are unstandardized beta coefficients (standard errors).

$*_{p}<0.05$

$* * p<0.01$

$* * * p<0.001$ 
Table 4: Average tenure length by SHO perceived personal attributes or capabilities most critical to own job performance

\begin{tabular}{|l|c|c|c|c|}
\hline Attribute or capability & Frequency & $\begin{array}{c}\text { Average Tenure for } \\
\text { those selecting this } \\
\text { attribute }\end{array}$ & $\begin{array}{c}\text { Average } \\
\text { Tenure for } \\
\text { others }\end{array}$ & P-Value \\
\hline $\begin{array}{l}\text { Ability to establish trust relationships } \\
\text { with agency staff }\end{array}$ & 57.4 & 5.1 & 4.0 & 0.145 \\
\hline Integrity & 47.2 & 3.9 & 5.3 & $\mathbf{0 . 0 3 8}$ \\
\hline $\begin{array}{l}\text { Ability to remain calm and confident } \\
\text { in the midst of challenge }\end{array}$ & 39.2 & 4.7 & 5.9 & 0.205 \\
\hline $\begin{array}{l}\text { Ability to establish trust relationships } \\
\text { with outside partners }\end{array}$ & 36.1 & 5.9 & 3.9 & $\mathbf{0 . 0 3 0}$ \\
\hline $\begin{array}{l}\text { Ability to establish trust relationships } \\
\text { with the governor's office }\end{array}$ & 28.7 & 6.1 & 4.1 & $\mathbf{0 . 0 5 0}$ \\
\hline Emotional intelligence & 23.1 & 3.7 & 4.9 & 0.158 \\
\hline $\begin{array}{l}\text { Ability to promote openness to } \\
\text { change within the agency }\end{array}$ & 23.1 & 4.0 & 4.9 & 0.316 \\
\hline Ability to learn from mistakes & 13.9 & 5.5 & 4.5 & 0.327 \\
\hline Self-awareness & 12.0 & 4.0 & 4.7 & 0.499 \\
\hline Conflict resolution ability & 6.5 & 3.5 & 4.7 & 0.379 \\
\hline Consistency & 5.6 & 3.3 & 4.7 & 0.351 \\
\hline Providing critical feedback & 4.1 & 4.0 & 5.5 & 0.545 \\
\hline
\end{tabular}

Note: SHOs were provided the list of 12 attributes/capabilities and asked to select the three that were most critical to their performance as a SHO. Statistical significance was measured at $p<0.05$. 
Table 5: Reasons for turnover among former SHOs

\begin{tabular}{|l|c|}
\hline Involuntary Turnover (54.2\%) & Frequency (\%) \\
\hline $\begin{array}{l}\text { I accepted a new position in anticipation of a } \\
\text { change in state administration }\end{array}$ & $19(43.2 \%)$ \\
\hline A new administration appointed another SHO & $16(36.4 \%)$ \\
\hline I left the position involuntarily & $10(22.7 \%)$ \\
\hline Total Involuntary Turnover & $\mathbf{4 5 ( 1 0 0 \% )}$ \\
\hline Voluntary Turnover (45.8\%) & Frequency (\%) \\
\hline I was offered another position & $17(47.2 \%)$ \\
\hline I resigned without securing my next position & $8(22.2 \%)$ \\
\hline I accomplished what I set out to do & $7(19.4 \%)$ \\
\hline I retired & $5(13.9 \%)$ \\
\hline I only committed to one term as SHO & $1(2.8 \%)$ \\
\hline Total Voluntary Turnover & $\mathbf{3 8 ( 1 0 0 \% )}$ \\
\hline
\end{tabular}


Appendix: After leaving SHO position, sector in which former SHOs obtained a job

\begin{tabular}{|l|c|c|c|c|}
\hline Sector & Total & $\begin{array}{c}\text { Voluntary } \\
\text { Turnover }\end{array}$ & $\begin{array}{c}\text { Involuntary } \\
\text { Turnover }\end{array}$ & $\mathbf{p}$-value \\
\hline Public Health & $46.0 \%$ & $32.1 \%$ & $57.1 \%$ & $\mathbf{0 . 0 4 8}$ \\
\hline Academia & $30.2 \%$ & $32.1 \%$ & $28.6 \%$ & 0.759 \\
\hline Health care & $20.6 \%$ & $25 \%$ & $17.1 \%$ & 0.444 \\
\hline Nonprofits including philanthropy & $20.6 \%$ & $14.3 \%$ & $25.7 \%$ & 0.265 \\
\hline Consulting & $19 \%$ & $21.4 \%$ & $17.1 \%$ & 0.667 \\
\hline Other governmental agency & $14.3 \%$ & $17.9 \%$ & $11.4 \%$ & 0.469 \\
\hline Retirement & $6.3 \%$ & $7.1 \%$ & $5.7 \%$ & 0.817 \\
\hline Pharmaceutical company & $3.2 \%$ & 0 & $5.7 \%$ & 0.199 \\
\hline Still searching for a position & $3.2 \%$ & 0 & $5.7 \%$ & 0.199 \\
\hline
\end{tabular}

Note: Answers were not mutually exclusive. Statistical significance was measured at $p<0.05$. 


\section{Literature Cited}

1. Beitsch LM, Brooks RG, Menachemi N, Libbey PM. Public health at center stage: new roles, old props. Health Affairs. 2006;25(4):911-922.

2. DeSalvo KB, O'Carroll PW, Koo D, Auerbach JM, Monroe JA. Public health 3.0: time for an upgrade. American journal of public health. 2016;106(4):621.

3. Xie JL, Johns G. Job scope and stress: Can job scope be too high? Academy of management journal. 1995;38(5):1288-1309.

4. Mosadeghrad AM. Occupational stress and turnover intention: implications for nursing management. International journal of health policy and management. 2013;1(2):169.

5. Mikkelsen A, Ogaard T, Lovrich N. Modeling the effects of organizational setting and individual coping style on employees subjective health, job satisfaction and commitment. Public Administration Quarterly. 2000:371-397.

6. Kesner IF, Dalton DR. Top management turnover and CEO succession: An investigation of the effects of turnover on performance. Journal of Management Studies. 1994;31(5):701-713.

7. Khurana R, Nohria N. The performance consequences of CEO turnover. 2000.

8. Khaliq AA, Thompson DM, Walston SL. Perceptions of hospital CEOs about the effects of CEO turnover. Hospital Topics. 2006;84(4):21-27.

9. Khaliq AA, Walston SL, Thompson DM. The Impact of Hospital CEO Turnover In US Hospitals Final Report. Chicago: American College of Healthcare Executives. 2006.

10. Grusky O. Managerial succession and organizational effectiveness. American Journal of Sociology. 1963;69(1):21-31.

11. Allen MP, Panian SK, Lotz RE. Managerial succession and organizational performance: A recalcitrant problem revisited. Administrative Science Quarterly. 1979:167-180.

12. Shen W, Cannella Jr AA. Revisiting the performance consequences of CEO succession: The impacts of successor type, postsuccession senior executive turnover, and departing CEO tenure. Academy of management journal. 2002;45(4):717-733.

13. Boaz Jr T, Johnson TE. Legally Established Qualifications and Methods of Appointment for State Health Officers. American Journal of Public Health and the Nations Health. 1951;41(1):7-12.

14. Halverson PK, Lumpkin JR, Yeager VA, Castrucci BC, Moffatt S, Tilson H. Research Full Report: High Turnover Among State Health Officials/Public Health Directors: Implications for the Public's Health. Journal of Public Health Management and Practice. 2017;23(5):537.

15. REMOVED TO PRESERVE BLINDED REVIEW. 
16. Foundation UH. America's Health Rankings Annual Report. United Health Foundation;2017.

17. Hambrick DC, Fukutomi GD. The seasons of a CEO's tenure. Academy of management review. 1991;16(4):719-742.

18. Schmid M, Limbach P, Scholz M. All Good Things Come to an End: CEO Tenure and Firm Value. 2016.

19. Baker EL, Castrucci BC, Moffatt S, et al. What State Health Officials Wish They Had Known and How They Learned Best. Journal of Public Health Management and Practice. 2018;24(1):85-86.

20. Serfling MA. CEO age and the riskiness of corporate policies. Journal of Corporate Finance. 2014;25:251-273.

21. Xu KT. State-level variations in income-related inequality in health and health achievement in the US. Social science \& medicine. 2006;63(2):457-464.

22. Asch DA, Jedrziewski MK, Christakis NA. Response rates to mail surveys published in medical journals. Journal of clinical epidemiology. 1997;50(10):1129-1136.

23. Newgard CD, Lewis RJ. Missing data: how to best account for what is not known. Jama. 2015;314(9):940-941.

24. 2017 Rhode Island General Laws Title 42 - State Affairs and Government Chapter 42-6 Departments of State Government Section 42-6-9 - Director of health. 2017. https://law.justia.com/codes/rhode-island/2017/title-42/chapter-42-6/section-42-6-9/. Accessed October 4, 2018. 